\title{
Estrous Cycle-Dependent Changes in Basal and Ethanol-Induced Activity of Cortical Dopaminergic Neurons in the Rat
}

\author{
Laura Dazzi**, 1,2,3, Emanuele Seu ${ }^{1,2,3}$, Giulia Cherchi ${ }^{1,2,3}$, Pier Paolo Barbieri ${ }^{1,2,3}$, Alessandra Matzeu ${ }^{1,2,3}$ \\ and Giovanni Biggio ${ }^{1,2,3}$ \\ 'Department of Experimental Biology 'B. Loddo,' University of Cagliari, Cagliari, Italy; ${ }^{2}$ Center of Excellence for Neurobiology of Dependence, \\ University of Cagliari, Cagliari, Italy; ${ }^{3}$ Unit of Neuropsychopharmacology, CNR Institute for Neuroscience, University of Cagliari, Cagliari, Italy
}

\begin{abstract}
The influence of the estrous cycle on dopamine levels in the rat medial prefrontal cortex under basal and ethanol-stimulated conditions was evaluated by microdialysis. The basal dopamine concentration in the dialysate varied markedly during the estrous cycle, being highest in estrus and lowest in proestrus. Furthermore, a challenge intraperitoneal administration of ethanol $(0.5 \mathrm{~g} / \mathrm{kg})$ induced a significant increase in dopaminergic output $(+50 \%)$ during estrus but had no effect in diestrus or proestrus. Ovariectomy or pretreatment with either finasteride (a $5 \alpha$-reductase inhibitor) or clomiphene (an estrogen receptor antagonist) prevented this ethanol-induced increase in dopamine concentration. The effect of ethanol was restored in ovariectomized rats by pretreatment with estrogen but not by that with progesterone. Our results thus show that the basal levels of dopamine in the prefrontal cortex are dependent on the phase of the estrous cycle. Furthermore, this dependence appears to be attributable to the effects of ovarian steroid hormones and results in a differential sensitivity of the dopaminergic neurons to ethanol. The hormone-induced changes in the activity of these neurons might contribute to the differences in drug sensitivity and mood state apparent among phases of the estrous cycle and between the sexes. Neuropsychopharmacology (2007) 32, 892-901. doi:I0.1038/sj.npp. I 30 I I 50; published online 12 July 2006
\end{abstract}

Keywords: ethanol; dopamine; estrogen; progesterone; estrous cycle; prefrontal cortex

\section{INTRODUCTION}

Clinical and experimental evidences have indicated that male and females differ in their behavioral and pharmacological responses to drugs of abuse, and in particular females appear to be more vulnerable than males to the reinforcing effects of psychostimulants, opiates, nicotine, and alcohol (Lynch et al, 2002; Roth et al, 2004; Carroll et al, 2004). Sex differences have been reported in animal models of all stages of drugs of abuse, including acquisition, maintenance, escalation, dependence, withdrawal, relapse, and treatment (Lynch et al, 2002; Roth et al, 2004; Carroll et al, 2004). Motivation to self-administer drugs of abuse in female rats varies as a function of the estrous cycle (Lynch et al, 2002), and ethanol consumption has been shown to be increased in women with premenstrual syndrome (Tobin et al, 1994; Chuong and Burgos, 1995; Allen, 1996). These observation, together with the evidence that no differences

* Correspondence: Professor L Dazzi, Department of Experimental Biology 'B. Loddo,' Neuroscience Section, Cittadella Universitaria, Monserrato, SS. 554, Km 4.500, 09042 Cagliari, Italy, Tel: + 39070675 4169, Fax: + 39070675 4166, E-mail: dazzi@unica.it

Received I February 2006; revised 5 April 2006; accepted 22 May 2006

Online publication: I June 2006 at http://www.acnp.org/citations/ Npp060106060065/default.pdf in ethanol pharmacokinetics have been associated with the different stages of the reproductive cycle both in rats (Robinson et al, 2002) and humans (Corrêa and Oga, 2004), suggest that sex differences in drug-seeking behavior as well as in drug sensivitity may be mediated by cyclic hormonal changes. Females are more susceptible than males to alcohol-related impairment of cognitive performance, especially in tasks involving delayed memory or divided attention functions (Savage et al, 2000), suggesting that mesocortical dopaminergic neurons might be involved in the modulation of cognitive impairments induced by this drug of abuse. In fact, dopaminergic neurons that project from the ventral tegmental area (VTA) to limbic and cortical regions of the forebrain play a major role in the physiological modulation of emotive and cognitive function (Goldman-Rakic, 1987; Jentsch et al, 1997; Sutton and Davidson, 1997). These neurons also contribute to the circuit responsible for drug reward (Pierce and Kalivas, 1997; Wolf, 1998; Childress et al, 1999; Tzschentke, 2001) as well as to the mediation of several effects of drugs of abuse including ethanol (Grace, 2000). Moreover, the activity of the mesocorticolimbic dopamine system shows sex differences (Becker, 1999) and is sensitive to modulation by the ovarian steroids estrogen and progesterone. Changes in the peripheral levels of these endogenous compounds are thus associated with those in the activity of nigrostriatal and 
mesolimbic dopaminergic systems (Becker, 1999). Estrogen also induces increases in dopamine turnover (Di Paolo et al, 1985, 1986) and amphetamine-stimulated release (Becker, 1990, 1999), decreases the number and sensitivity of preand postsynaptic $\mathrm{D}_{2}$ dopamine receptors (Bazzett and Becker, 1994; Thompson et al, 2001; Zhou et al, 2002; Febo et al, 2003), and increases the density of the dopamine reuptake protein (Di Paolo et al, 1988; Morissette and Di Paolo, 1993). Progesterone, the precursor of the neuroactive steroid $3 \alpha$-hydroxy- $5 \alpha$-pregnan-20-one (allopregnanolone, or $3 \alpha, 5 \alpha$-THPROG), which is one of the most potent positive modulators of $\mathrm{GABA}_{\mathrm{A}}$ receptor function (Majewska et al, 1986; Majewska, 1992), decreases both basal and stimulated mesocortical dopaminergic transmission (Motzo et al, 1996; Dazzi et al, 2002b), as do other GABAergic drugs.

Both estrogen (McEwen and Parsons, 1982; Becker and Cha, 1989; Xiao and Becker, 1994; Dluzen, 2005) and ethanol (Phillips and Shen, 1996; Samson et al, 1997; Brodie and Appel, 1998) increase the activity of striatal dopaminergic neurons. The increase in the concentration of the progesterone metabolite $3 \alpha, 5 \alpha$-THPROG in rat brain elicited by systemic administration of ethanol correlates with the hypnotic, anticonvulsant, and sedative effects of ethanol (VanDoren et al, 2000). The local application of ethanol also increases the concentration of $3 \alpha, 5 \alpha$-THPROG as well as the amplitude of $\mathrm{GABA}_{\mathrm{A}}$ receptor-mediated inhibitory potentials recorded from pyramidal neurons in isolated hippocampal slices (Sanna et al, 2004). Furthermore, $3 \alpha, 5 \alpha$-THPROG is able to substitute for ethanol in a discriminative stimulus paradigm in both primates and rats (Bowen et al, 1999; Engel and Grant, 2001), to protect against seizures induced by ethanol withdrawal in rats (Finn et al, 2004; Devaud et al, 1995), and to potentiate the effect of an acute administration of ethanol on cortical dopaminergic neurons (Dazzi et al, 2002a).

Given the roles of estrogen and progesterone in modulation of the basal and ethanol-stimulated activity of dopaminergic neurons, the marked fluctuations in the plasma and cerebral concentrations of these ovarian hormones might be expected to contribute substantially to the changes in mood, cognitive performance, and drug sensitivity associated with progression through the menstrual cycle. The subunit composition of $\mathrm{GABA}_{\mathrm{A}}$ receptors in the brain has recently been shown to change markedly during the estrous cycle (Griffiths and Lovick, 2005; Lovick et al, 2005; Maguire et al, 2005), with these changes possibly having an impact on the threshold of excitability of various neuronal populations. These observations, together with the ability of both estrogen and progesterone to alter the function of GABAergic and dopaminergic systems, both of which are implicated in the behavioral and physiological effects of ethanol (Phillips and Shen, 1996; Koob et al, 1998), further suggest that these hormones may differentially influence the subjective, behavioral, and physiological effects of ethanol at different phases of the reproductive cycle.

To evaluate whether changes in estrogen and progesterone levels would affect the response of mesocortical dopaminergic neurons to ethanol, we have measured the basal levels of dopamine in dialysis samples collected from the prefrontal cortex of intact cycling female rats as well as the response of mesocortical dopaminergic neurons to an acute administration of ethanol at the different phases of the estrous cycle and after ovariectomy.

\section{MATERIALS AND METHODS}

\section{Animals}

Female Sprague-Dawley CD rats (Charles River, Como, Italy), with initial body masses of 200 to $220 \mathrm{~g}$, were maintained under an artificial 12-h-light, 12-h-dark cycle (light on $0800-2000$ hours) at a temperature of $22 \pm 2{ }^{\circ} \mathrm{C}$ and $65 \%$ humidity and with free access to standard food (Stefano Morini, San Polo D’Enza, Reggio Emilia, Italy) and water. The rats were acclimated to the animal facility for at least 8 days before experiments. Animal care and handling throughout the experimental procedures were in accordance with the statement revised and approved by the Society for Neuroscience in January 1995 and with the European Communities Council Directive of 24 November 1986 (86/609/EEC). The experimental protocols were also approved by the Animal Ethics Committee of the University of Cagliari.

\section{Drugs}

Ethanol (20\%, w/v) was administered intraperitoneally (i.p.) at a dose of $0.5 \mathrm{~g} / \mathrm{kg}$ of body mass. Progesterone was dissolved in olive oil by sonication for $4 \mathrm{~h}$ and was administered i.p. at a dose of $5 \mathrm{mg} / \mathrm{kg}$ in a volume of $2 \mathrm{ml} / \mathrm{kg}$. Ethynylestradiol (a synthetic estrogen) was dissolved in distilled water with one drop of Tween 80 per $5 \mathrm{ml}$ of solution and was injected subcutaneously (s.c.) at a dose of $30 \mu \mathrm{g}$ per rat in $1 \mathrm{ml}$. Finasteride (a specific $5 \alpha$ reductase inhibitor) was obtained as Prostide tablets (Sigma Tau, Milan, Italy) containing $25 \mathrm{mg}$ of the drug (Trapani et al, 2002 ); it was dissolved in $20 \%$ (w/v) 2-hydroxypropyl- $\beta$ cyclodestrin by sonication for $2 \mathrm{~h}$ and administered s.c. at a dose of $25 \mathrm{mg} / \mathrm{kg}$ in a volume of $3 \mathrm{ml} / \mathrm{kg}$. Progesterone, ethynylestradiol, and finasteride were administered 25 and $1 \mathrm{~h}$ before the onset of microdialysis experiments (at 0800 hours on the day of surgery and at 0800 hours on the day of the experiment). The time points for treatment with each of the steroids or drugs have been selected on the basis of previous results from our lab in which both $3 \alpha, 5 \alpha$ THPROG levels and dopamine activity have been measured after administration of these compounds (Dazzi et al, 2002a,b). Clomiphene (an estrogen receptor antagonist) was dissolved in distilled water with one drop of Tween 80 per $5 \mathrm{ml}$ and was administered i.p. at a dose of $5 \mathrm{mg} / 3 \mathrm{ml} / \mathrm{kg}$. Control rats received an equal volume of the respective vehicle.

\section{Drug Treatment Protocols and Ovariectomy}

The estrous cycle in the rat comprises four phases (estrus, diestrus 1, diestrus 2, proestrus) and has an average duration of 4 days. We determined the different phases of the estrous cycle from vaginal smears obtained daily at 0900 hours for about 2 weeks (two to four cycles) before experiments. Each phase is characterized by a specific number and morphology of cells in the vaginal fluid as revealed by light microscopy (Jablonka-Shariff et al, 1999) (Figure 1). Only animals with a regular estrous cycle (stages 

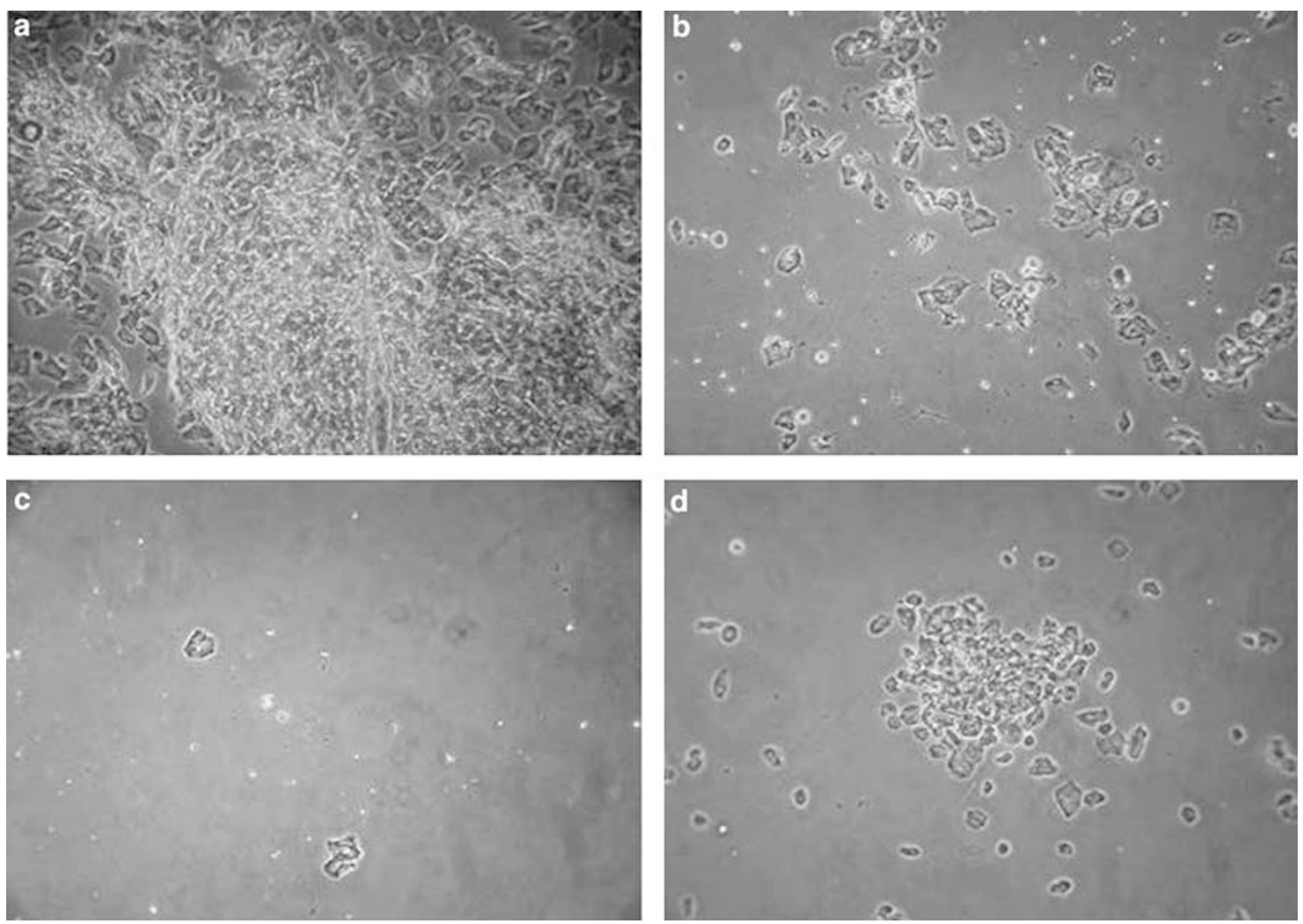

Figure I Microscopic identification of the different phases of the estrous cycle. Estrus (a), diestrus I (b), diestrus 2 (c), and proestrus (d) are each characterized by the number and morphology of the cells in vaginal fluid. Magnification $\times 100$.

are in sequence and the entire cycle lasts $4-5$ days) were used for experiments. Intact female rats in different phases of the estrous cycle were subjected to surgery for the insertion of a microdialysis probe. Microdialysis was initiated $24 \mathrm{~h}$ after probe implantation; when the concentration of dopamine had stabilized, ethanol $(0.5 \mathrm{~g} / \mathrm{kg}$, i.p.) was administered. Other intact female rats were pretreated with either the estrogen receptor antagonist clomiphene $(5 \mathrm{mg} /$ $\mathrm{kg}$, i.p.) or the $5 \alpha$-reductase inhibitor finasteride $(25 \mathrm{mg} / \mathrm{kg}$, s.c.) before the acute administration of ethanol.

Female rats at least 2 months old, with body masses of 220-250 g, were anesthetized with Equithesin solution $(162 \mathrm{ml}$ of nembutal, $42.5 \mathrm{~g}$ of chloral hydrate, $21.26 \mathrm{~g}$ of $\mathrm{MgSO}_{4}, 396 \mathrm{ml}$ of propylene glycol, and $100 \mathrm{ml}$ of ethanol, adjusted to a volume of 11 with distilled water) at a dose of $3 \mathrm{ml} / \mathrm{kg}$ (i.p.). The ovaries of rats were removed through two lateral cuts at the abdominal level. Control rats were anesthetized and subjected to sham surgery, without removal of the ovaries. The animals were then housed for 2 weeks in groups of four per cage to allow full recovery from the surgery. Beginning 1 week after surgery, vaginal smears were collected daily to confirm the loss of ovarian function; all ovariectomized (OVX) rats presented a smear consisting almost exclusively of a few leukocytes, similar to that observed in diestrus 2 for intact females. At 2 or 4 weeks after ovariectomy, the rats were anesthetized to allow insertion of a microdialysis probe and were divided into groups that were pretreated with various drugs before the acute administration of ethanol.

\section{Implantation of the Microdialysis Probe and Experimental Procedures}

Rats were anesthetized with chloral hydrate $(0.4 \mathrm{~g} / \mathrm{kg}$, i.p.) and a concentric dialysis probe was inserted at the level of the medial prefrontal cortex $(\mathrm{A}+3.2, \mathrm{ML}+0.8, \mathrm{~V}-5.3$ relative to the bregma) according to the Paxinos atlas (Paxinos and Watson, 1982). The active length of the dialysis membrane (Hospal Dasco, Bologna, Italy) was restricted to $2 \mathrm{~mm}$.

Experiments were performed $24 \mathrm{~h}$ after probe implantation, beginning at 0900 hours. Ringer's solution containing $125 \mathrm{mM} \mathrm{KCl}, 1.3 \mathrm{mM} \mathrm{CaCl}_{2}, 1 \mathrm{mM} \mathrm{MgCl} 2,23 \mathrm{mM} \mathrm{NaHCO}_{3}$, and $1.5 \mathrm{mM}$ potassium phosphate $(\mathrm{pH} 7.3)$ was pumped through the dialysis probe at a constant rate of $2 \mu \mathrm{l} / \mathrm{min}$. Samples of dialysate were collected every $20 \mathrm{~min}$ and immediately analyzed for dopamine by high-performance liquid chromatography with electrochemical detection. The system consisted of an isocratic pump, an electrochemical detector (LC4B; BAS Bioanalytical System, West Lafayette, IN) operating at $+650 \mathrm{mV}$ relative to an $\mathrm{Ag} / \mathrm{AgCl}$ reference electrode, and an LC18DB column (750 by $4.6 \mathrm{~mm}$; Supelco $3 \mu \mathrm{m})$. The mobile phase consisted of $73.4 \mathrm{mM}$ potassium phosphate buffer (pH 3.0), $3 \mathrm{mM}$ octane-2-sulfonic acid, $0.1 \mathrm{mM}$ EDTA, and $10 \%(\mathrm{v} / \mathrm{v})$ methanol, and was pumped at a flow rate of $1 \mathrm{ml} / \mathrm{min}$. Absolute dopamine concentrations were determined with the use of external standards; the detection limit for dopamine was $2 \mathrm{fmol}$ per injection. The average neurotransmitter concentration in the last three samples before treatment was taken as $100 \%$, and 
post-treatment values were expressed as a percentage of the basal value. The mean in vitro recovery of the probes was $24 \pm 3 \%$. All probes were tested before implantation, and those with a recovery value outside of this range were not used.

At the end of each experiment, rats were transcardially perfused with $100 \mathrm{ml}$ of physiological saline followed by $500 \mathrm{ml}$ of a solution containing $4 \%$ formaldehyde, $1 \%$ calcium acetate, and $100 \mathrm{mM} \mathrm{NaCl}$. The probe was removed, the brain was cut with the use of a Vibratome into serial coronal sections, and the placement of the probe was verified histologically. All rats in which the probe was located outside of the prefrontal cortex were excluded from the analysis. The locations of the probes were reconstructed

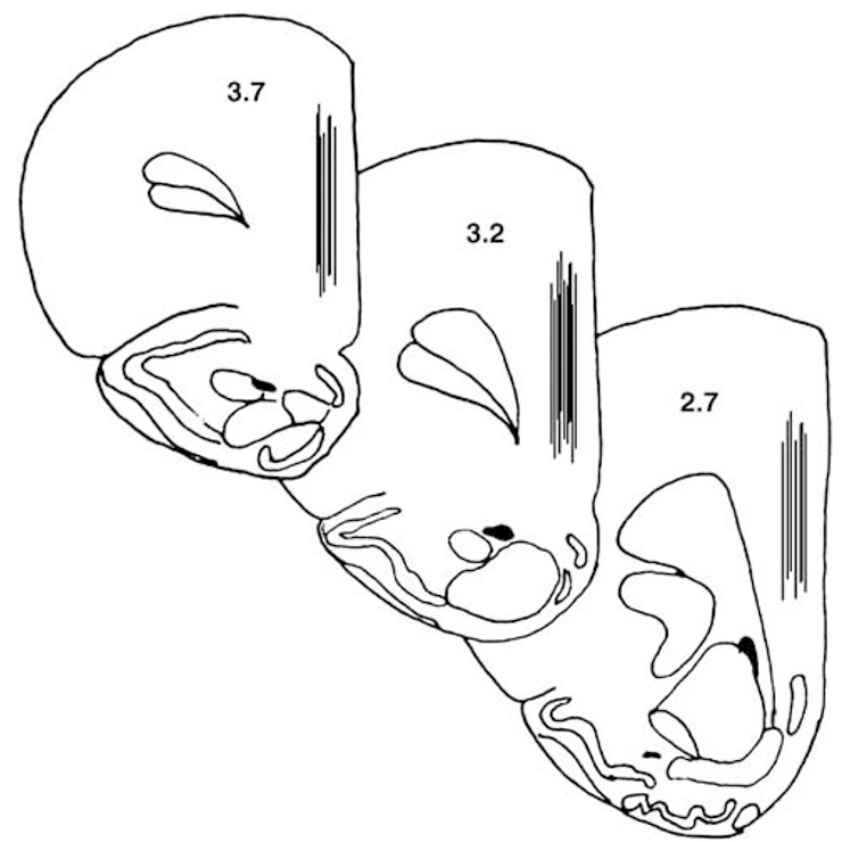

Figure 2 Localization of the dialysis probes within the prefrontal cortex (according to Paxinos and Watson, 1982). Numbers in the sections represent anteriority.

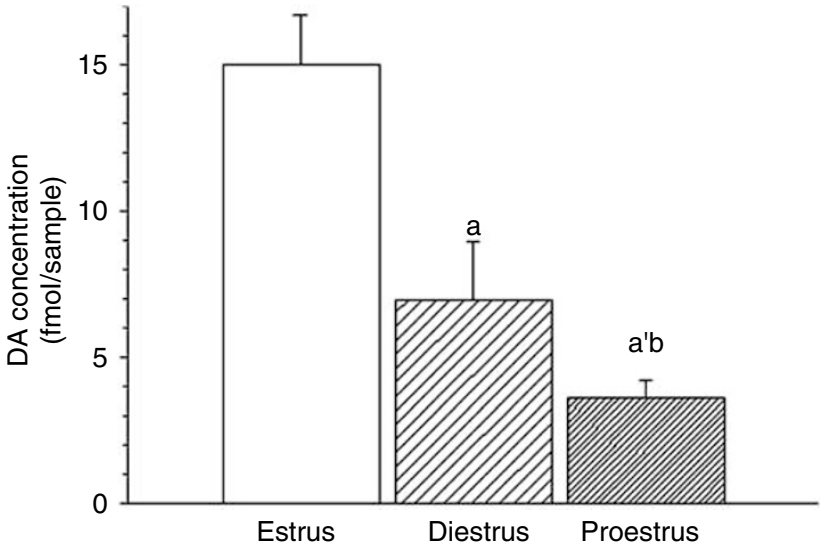

Figure 3 Changes in the basal concentration of dopamine in dialysate sample from the prefrontal cortex during the estrous cycle. Data are means \pm SEM for at least 10 rats per group and are expressed as femtomoles of dopamine (DA) per $40-\mu$ l sample. ${ }^{a} P<0.05,{ }^{a} P<0.0$ I vs basal value in estrus; ${ }^{b} P<0.01$ vs basal value in diestrus. and referred to the atlas of Paxinos and Watson (1982) (Figure 2).

\section{Statistical Analysis}

Data are presented as means \pm SEM. Comparisons among groups were performed by one-way analysis of variance (ANOVA) for the data in Figure 3 or by two-way ANOVA for repeated measures, with factors being cycle phase and time points, for the data in Figure 4 and pretreatment and treatment for the data in Figures 5-7. The raw baseline values of dopamine concentration were used for statistical

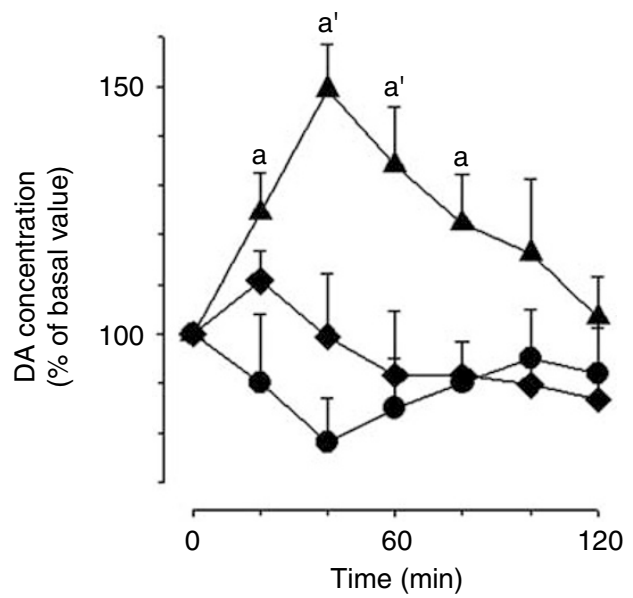

Figure 4 Effects of acute administration of ethanol $(0.5 \mathrm{~g} / \mathrm{kg}$, i.p. $)$ on the basal concentration of dopamine in dialysate sample from the prefrontal cortex during estrus (triangles), diestrus (diamonds), or proestrus (circles). Data are means \pm SEM for at least five rats per group and are expressed as a percentage of the corresponding basal value. ${ }^{a} P<0.05$, ${ }^{a} P<0.0$ I vs basal value.

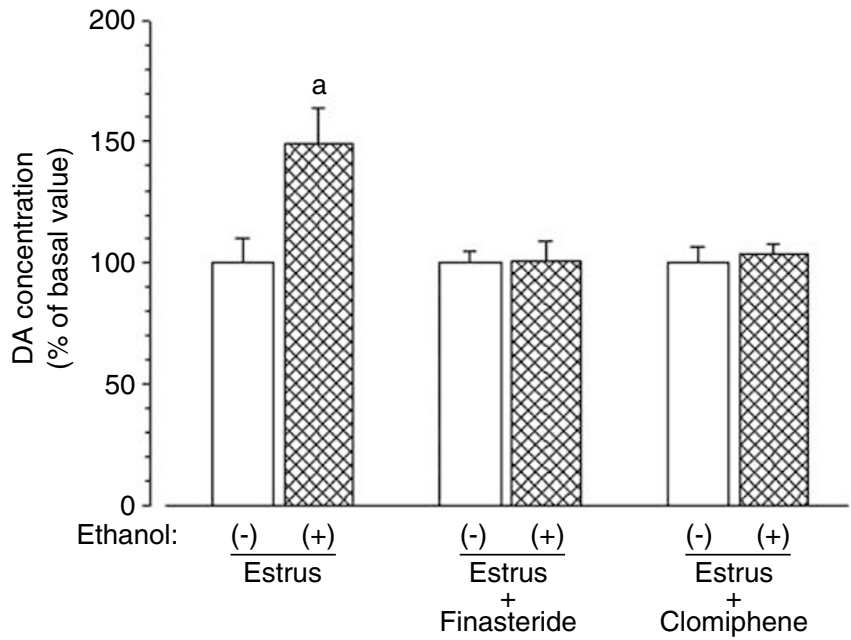

Figure 5 Effects of pretreatment with the estrogen receptor antagonist clomiphene $(5 \mathrm{mg} / \mathrm{kg}$, i.p.) or the $5 \alpha$-reductase inhibitor finasteride $(25 \mathrm{mg} /$ $\mathrm{kg}$, s.c.) on the ethanol-induced increase in the dopamine output in the prefrontal cortex during estrus. Finasteride was administered 25 and I h, and clomiphene was administered I h, before the onset of microdialysis. Data are expressed as means \pm SEM for at least five rats per group, are expressed as a percentage of the corresponding basal value, and were obtained I h after the administration of ethanol $\left(0.5 \mathrm{~g} / \mathrm{kg}\right.$, i.p.). ${ }^{a} P<0.0 \mathrm{I}$ vs the basal value. 


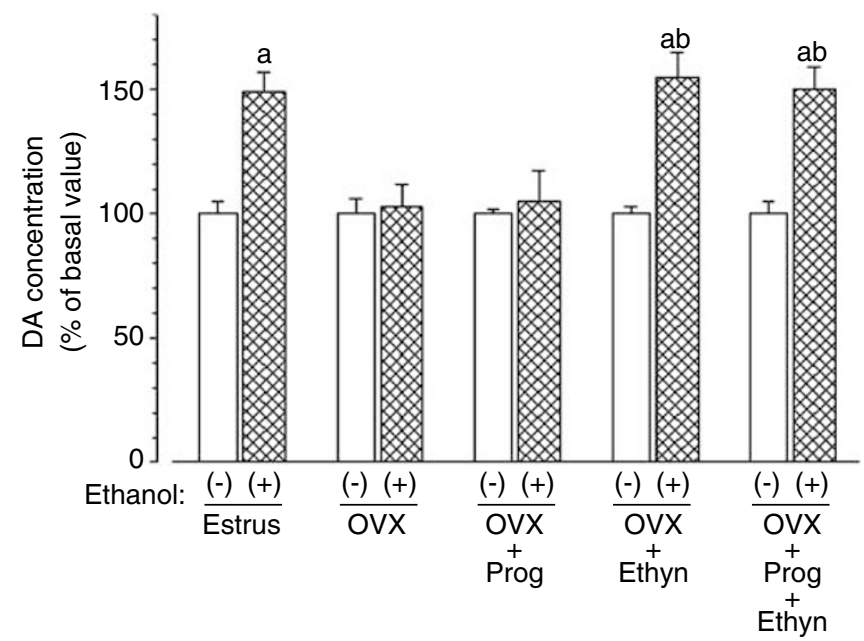

Figure 6 Effects of ovariectomy and of pretreatment with ethynylestradiol or progesterone in OVX rats on the ethanol-induced increase in cortical dopamine output. Female rats were subjected to ovariectomy 2 weeks before experiments. They were pretreated with vehicle, ethynylestradiol (30 $\mu$ g, s.c.), progesterone ( $5 \mathrm{mg} / \mathrm{kg}$, i.p.), or the combination of ethynylestradiol and progesterone both 25 and I h before the onset of microdialysis. They were then subjected to an intraperitoneal challenge with ethanol $(0.5 \mathrm{~g} / \mathrm{kg})$, and the cortical concentration of dopamine was determined $60 \mathrm{~min}$ later. The effect of ethanol was also determined for sham-operated rats in estrus. Data are expressed as a percentage of the corresponding basal value and are means \pm SEM for at least five rats per group. ${ }^{\mathrm{a}} P<0.0$ I vs basal value; ${ }^{\mathrm{b}} P<0.0$ I vs the corresponding value for control animals (OVX rats pretreated with vehicle).

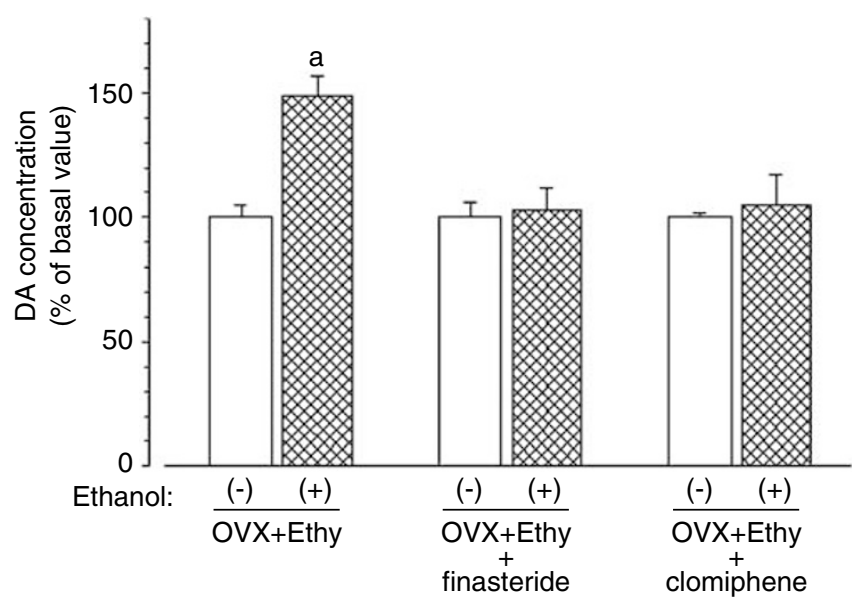

Figure 7 Effects of clomiphene or finasteride on the ethanol-induced increase in dopamine output in OVX rats pretreated with ethynylestradiol. Female rats were subjected to ovariectomy 2 weeks before experiments. Ethynylestradiol ( $30 \mu$ g, s.c.) and finasteride $(25 \mathrm{mg} / \mathrm{kg}$, s.c.) were administered 25 and $\mathrm{I} \mathrm{h}$, and clomiphene $(5 \mathrm{mg} / \mathrm{kg}$, i.p.) was administered $\mathrm{I} \mathrm{h}$, before the onset of microdialysis. Rats were then subjected to an intraperitoneal challenge with ethanol $(0.5 \mathrm{~g} / \mathrm{kg})$. Data are expressed as a percentage of the corresponding basal value, are means \pm SEM for at least five rats per group, and represent the maximal value obtained $60 \mathrm{~min}$ after ethanol administration. ${ }^{\mathrm{a}} P<0.0$ I vs basal value.

analysis. Absolute basal dopamine concentrations are reported in the Results section. Post hoc comparisons were performed by Neuman-Keuls test. A $P$-value of $<0.05$ was considered statistically significant.

\section{RESULTS}

Changes in the Basal Levels of Dopamine in the Dialysates from Rat Prefrontal Cortex during the Estrous Cycle

We first measured the basal levels of dopamine in the prefrontal cortex of female rats during the estrous cycle (Figure 3). Given that the basal dopamine concentration did not differ between diestrus 1 and diestrus $2(P=2.056)$, the values for these two phases were combined and are subsequently referred to as the diestrus value. The basal dopamine concentration was maximal during estrus $(15 \pm 1.7 \mathrm{fmol}$ per $40-\mu \mathrm{l}$ sample), was markedly decreased during diestrus $(6.9 \pm 2.0 \mathrm{fmol})$, and was lowest during proestrus $(3.6 \pm 0.6 \mathrm{fmol})$. ANOVA revealed a significant effect of cycle phase on basal dopamine concentration $(\mathrm{F}(2,31)=14.5477, P<0.001)$.

\section{Differential Effects of Ethanol on Dopamine Output in the Prefrontal Cortex during the Estrous Cycle}

Similar to our previous observations with male rats (Dazzi et al, 2002a), i.p. administration of ethanol $(0.5 \mathrm{~g} / \mathrm{kg})$ induced a marked increase in cortical dopamine output in female rats during estrus (Figure 4). This increase was maximal $(+50 \%) 40$ min after ethanol administration and was no longer apparent at $100 \mathrm{~min}$. The same dose of ethanol administered to different groups of female rats in diestrus or proestrus failed to significantly affect the basal concentration of dopamine. ANOVA revealed a significant main effect of cycle phase $(\mathrm{F}(2,144)=2.5689, P<0.001)$, a significant main effect of repeated measures $(F(6,144)=$ 4.7983, $P<0.001)$, and a significant interaction between factors $(\mathrm{F}(12,144)=8.4625, P<0.001)$.

\section{Inhibition of the Ethanol-Induced Increase in Cortical Dopamine Output during Estrus by Clomiphene, Finasteride, or Ovariectomy}

The acute administration of the estrogen receptor antagonist clomiphene $(5 \mathrm{mg} / \mathrm{kg}$, i.p.) prevented the ethanolinduced increase in dopamine concentration observed during estrus (Figure 5). ANOVA revealed a significant main effect of pretreatment $(F(1,10)=2.8309, P<0.001)$, a significant main effect of treatment $(\mathrm{F}(1,10)=2.7285$, $P<0.001)$, and a significant interaction between factors $(\mathrm{F}(1,10)=0.9259 ; P<0.001)$. Administration of the $5 \alpha$ reductase inhibitor finasteride $(25 \mathrm{mg} / \mathrm{kg}$, s.c., once a day for 2 days) also completely inhibited the ethanol-induced increase in cortical dopamine output during estrus. ANOVA again revealed a significant main effect of pretreatment $(\mathrm{F}(1,12)=4.0394, P<0.001)$, a significant main effect of treatment $(\mathrm{F}(1,12)=2.1819, P<0.001)$, and a significant interaction between factors $(\mathrm{F}(1,12)=1.0394, P<0.001)$.

To clarify further the roles of progesterone and estrogen in the effect of ethanol on cortical dopaminergic neurons, we evaluated the effect of this drug on dopamine concentration in OVX rats. The basal dopamine concentration in dialysate sample from the prefrontal cortex of OVX rats was $5.9 \pm 1.4 \mathrm{fmol}$ per $40-\mu \mathrm{l}$ sample, a value similar to that for intact female rats during diestrus (Figure 3 ). The administration of ethanol to OVX rats, however, failed 
to increase dopamine output in the prefrontal cortex (Figure 6). ANOVA revealed a significant main effect of ovariectomy $(\mathrm{F}(1,9)=3.3717, \quad P<0.001)$, a significant main effect of treatment $(\mathrm{F}(1,9)=3.0221, P<0.001)$, and a significant interaction between factors $(F(1,9)=0.063$, $P<0.001)$.

\section{Effects of Progesterone and Ethynylestradiol on the Sensitivity of Mesocortical Dopaminergic Neurons to Ethanol in OVX Rats}

To better understand the relative roles of estrogen and progesterone in the effect of ethanol on mesocortical dopaminergic neurons, we examined whether the ethanolinduced increase in dopamine output could be restored in OVX rats by prior administration of progesterone $(5 \mathrm{mg} / \mathrm{kg}$, i.p., once a day for 2 days) or the synthetic estrogen ethynylestradiol (30 $\mu$ g, s.c., once a day for 2 days) (Figure 6). The acute administration of ethanol failed to significantly affect dopamine concentration in the prefrontal cortex of OVX rats pretreated with progesterone $(\mathrm{F}(1,11)=0.0245, P=0.6497)$. In contrast, ethanol induced a significant increase $(+55 \%)$ in dopamine output in OVX rats pretreated with ethynylestradiol $(\mathrm{F}(1,12)=2.9746$, $P<0.001)$; the magnitude of this effect of ethanol was similar to that apparent in sham-operated female rats using estrus. The same dose of ethynylestradiol administered 30 days (rather than 2 weeks) after ovariectomy failed to restore the ethanol-induced increase in dopamine concentration $(\mathrm{F}(1,11)=0.0152, P=0.8624)$ (data not shown). The combined administration of progesterone and ethynylestradiol in OVX rats did not modify further the effect of ethanol $(+50 \%$ increase $)$ on cortical dopamine output relative to administration of ethynylestradiol alone $(\mathrm{F}(1,12)=0.1163, P=0.4354)$.

The ethanol-induced increase in the extracellular dopamine concentration in OVX rats pretreated with ethynylestradiol was prevented by clomiphene $(\mathrm{F}(1,10)=2.6598$, $P<0.001)$ (Figure 7). Finasteride also completely inhibited the ability of ethanol to increase mesocortical dopaminergic output in OVX rats pretreated with ethynylestradiol $(\mathrm{F}(1,10)=2.2658, P<0.001)$ (Figure 7$)$.

\section{DISCUSSION}

We have shown that there are marked differences in the concentration of dopamine in dialysate sample from the prefrontal cortex of female rats in the different phases of the estrous cycle, with the highest concentration apparent during estrus and the lowest during proestrus. Consistent with our data, previous studies have shown that the basal concentration of dopamine in the striatum and nucleus accumbens of rats is dependent on the circulating levels of estrogen and progesterone (Becker, 1999). Moreover, we have also now shown that the mesocortical dopaminergic pathway is sensitive to the acute administration of ethanol $(0.5 \mathrm{~g} / \mathrm{kg}$, i.p.) during estrus but not during diestrus or proestrus. Furthermore, the ethanol-induced increase in dopamine concentration was prevented by ovariectomy and restored in OVX rats by pretreatment with a synthetic estrogen but not by that with progesterone, suggesting that estrogen plays a more important role than does progesterone in modulation of this effect of ethanol in female rats. In contrast, we previously showed that an increase in the brain content of $3 \alpha, 5 \alpha$-THPROG, induced by administration of its precursor progesterone, enhanced the ethanol-induced biphasic effect on cortical dopamine output in male rats (Dazzi et al, 2002a) and that this effect was abolished by the $5 \alpha$-reductase inhibitor finasteride, which blocks the formation of $3 \alpha, 5 \alpha$-THPROG from progesterone.

Estrogen exerts a wide range of actions in the mammalian brain that extend far beyond its classical role as regulator of the hypothalamo-pituitary-gonadal axis. These actions include neurotrophic effects, such as promotion of cell survival (Sawada and Shimohama, 2003), modulation of synaptogenesis (Naftolin et al, 1996; Stein, 2001) and axonal and dendritic sprouting (Garcia-Segura et al, 2001; Leranth et al, 2000), and enhancement of neurogenesis (Beyer, 1999; Tanapat et al, 1999). A functional relation between the ability of estrogen to increase the synthesis of brain-derived neurotrophic factor and an increase in the excitability of specific neuronal populations in the rat hippocampus has also been demonstrated (Scharfman et al, 2003). In addition, estrogen modulates certain brain functions by affecting neurotransmitter levels within distinct neuronal populations as well as the expression of receptors and second messengers (Becker, 1990, 1999). Indeed, estrogen affects the concentration of dopamine in specific brain areas and induces rapid changes in the response of striatal neurons to $D_{1}$ and $D_{2}$ dopamine receptor agonists (Febo et al, 2003), possibly by producing an uncoupling of the $D_{2}$ receptor $-\mathrm{G}$ protein complex (Dluzen, 2005). Prolonged estrogen administration induces downregulation of presynaptic dopamine activity (Di Paolo et al, 1982; Morissette and Di Paolo, 1993) and produces a dopamine receptor supersensitivity (Hruska and Silbergeld, 1980; Di Paolo et al, 1981, 1982; Hruska, 1986) that results in a release from the inhibitory action of these receptors and enhancement of stimulated dopamine release. Moreover, estrogen increases the activity of the dopamine transporter in a manner dependent on phase of the estrous cycle, with higher activity during proestrus and lower activity in estrus (Morissette and Di Paolo, 1993; Thompson and Moss, 1997). Together, these various observations indicate that estrogen may play a major role in modulation of basal and ethanol-stimulated activity of cortical dopaminergic neurons. Consistent with this notion, we have now shown that blockade of estrogen receptors with clomiphene prevented both the effect of ethanol on the cortical concentration of dopamine in intact female rats during estrus as well as the ability of ethynylestradiol to restore this effect of ethanol in OVX rats. Estrogen may thus increase the activity of cortical dopaminergic neurons through a combination of mechanisms, including a reduction in inhibitory control exerted by autoreceptors (Hruska and Silbergeld, 1980; Di Paolo et al, 1981, 1982; Hruska, 1986), an increase in the activity of the dopamine transporter (Morissette and Di Paolo, 1993; Thompson and Moss, 1997), inhibition of $\mathrm{Ca}^{2+}$ influx (Mermelstein et al, 1996), uncoupling of the $D_{2}$ receptor $-G$ protein complex (Dluzen, 2005), and modulation of neuronal plasticity (Naftolin et al, 1996; Beyer, 1999; Tanapat et al, 1999; Garcia-Segura et al, 2001; Leranth et al, 2000; Stein, 2001; Sawada and Shimohama, 2003; Scharfman et al, 2003). 
Estrogen depletion induced by ovariectomy results in a marked decrease in dopaminergic cell density in the brain of nonhuman primates (Leranth et al, 2000), an effect that can be reversed by estrogen administration 10 days, but not 30 days, after ovariectomy. These results suggest that estrogen is necessary to maintain dopamine cells trophic and active and that a more prolonged estrogen depletion, as observed 30 days after ovariectomy, may result in the death of dopamine neurons. Our finding that estrogen administration 30 days after ovariectomy failed to restore the effect of ethanol on cortical dopaminergic neurons is consistent with the notion that estrogen is necessary to ensure an optimal level of dopaminergic neurotransmission. Thus, estrogen administration 14 days after ovariectomy would still be able to increase the activity of dopaminergic neurons, whereas it looses this capability after 30 days of estrogen depletion when at least part of the mesocortical dopamine neurons might be inactive or dead.

Similar to the effect of clomiphene and ovariectomy, the selective $5 \alpha$-reductase blocker finasteride, which inhibits the conversion of progesterone to $3 \alpha, 5 \alpha$-THPROG, prevented the increase in dopamine output elicited by ethanol during estrus, indicating that both estrogen and progesterone might be necessary for the effect of ethanol on mesocortical dopaminergic neurons in female rats. Ethanol increases both peripheral (Van Doren et al, 2000) and central (Sanna et al, 2004) synthesis of $3 \alpha, 5 \alpha$-THPROG and modulates expression of the genes for various $\mathrm{GABA}_{\mathrm{A}}$ receptor subunits (Cagetti et al, 2003; Follesa et al, 2003; Sanna et al, 2003). The presence of progesterone as a source of $3 \alpha, 5 \alpha$-THPROG, which by acting at $\mathrm{GABA}_{\mathrm{A}}$ receptors mediates most of the behavioral, neurochemical, and molecular effects of ethanol (Morrow et al, 2001; Van Doren et al, 2000; Dazzi et al, 2002a; Sanna et al, 2003, 2004), seems to be required for many of the actions of this addictive substance. The possibility, however, that clomiphene and/or finasteride may antagonize the ethanolinduced increase in cortical dopamine output by acting at sites distal from where the ethynyl estradiol is acting, or by alternate mechanisms than the primary effect of these drugs, cannot be excluded.

The observation that 14 days after ovariectomy, ethynylestradiol pretreatment alone was able to restore the effect of ethanol on cortical dopamine output appears to contradict this hypothesis. However, although ovariectomy greatly reduces the amount of progesterone both in plasma and the brain, it does not completely eliminate it (Morissette and Di Paolo, 1993; Follesa et al, 2002), suggesting that the amount of this steroid remaining in the brain of OVX rats might be sufficient to potentiate the effect of estrogen. Our recent observation that ethanol increases brain steroidogenesis by a local action (Sanna et al, 2004), together with the suggestion that the antiseizure effect of estrogen might be mediated by formation of $3 \alpha, 5 \alpha$-THPROG (Frye and Rhodes, 2005), support the idea that the brain level of this neuroactive steroid might be increased by ethynylestradiol and ethanol administration to an extent sufficient for it to be able to potentiate estrogen action. This conclusion is further supported by our observation that finasteride abolished the ethanol-induced increase in the cortical extracellular concentration of dopamine in OVX rats pretreated with ethynylestradiol. Synergistic interactions between estrogen and $3 \alpha, 5 \alpha$-THPROG have also been described previously (Canonaco et al, 1989; Landgren and Selstam, 1995; Frye and Duncan, 1996; Wihlback et al, 2005).

Short-term exposure to progesterone affects the expression of $\mathrm{GABA}_{\mathrm{A}}$ receptor subunits and consequently the pharmacological properties of the receptors. In particular, such exposure to progesterone or to its metabolite $3 \alpha, 5 \alpha-$ THPROG increases the expression of the $\alpha 4$ subunit (Gulinello and Smith, 2003), the presence of which renders $\mathrm{GABA}_{\mathrm{A}}$ receptors insensitive to benzodiazepines and confers to flumazenil the ability to act as a positive modulator (Wafford et al, 1996). The subunit composition of $\mathrm{GABA}_{\mathrm{A}}$ receptors is also thought to determine receptor sensitivity to ethanol. However, whereas low concentrations of ethanol were shown to selectively increase GABA-gated currents at receptors containing both $\alpha 4$ and $\delta$ subunits (Sundstrom-Poromaa et al, 2002; Wallner et al, 2004), a more recent study failed to confirm this finding (Borghese et al, 2005). Expression of the $\alpha 4$ subunit was also increased in vitro in cerebellar and hippocampal cell cultures (Follesa et al, 2000) as well as in vivo in the brain of rats (Biggio et al, 2003; Follesa et al, 2004) by chronic exposure to and subsequent withdrawal of progesterone, a paradigm that has been proposed to replicate the hormonal facets of premenstrual syndrome (Sundstrom-Poromaa et al, 2002). Another possible explanation for the difference in the effect of ethanol on dopaminergic neurons during the different phases of the estrous cycle is thus that physiological fluctuations in the concentration of progesterone during the estrous cycle lead to changes in the expression of $\mathrm{GABA}_{\mathrm{A}}$ receptor subunits that, in turn, result in the synthesis of $\mathrm{GABA}_{\mathrm{A}}$ receptors with different sensitivities to ethanol. Indeed, the subunit composition of $\mathrm{GABA}_{\mathrm{A}}$ receptors in various regions of the brain of mice and rats has been shown to change during progression of the estrous cycle (Griffiths and Lovick, 2005; Lovick et al, 2005; Maguire et al, 2005). The stimulatory effect of ethanol on cortical dopaminergic neurons was evident only during estrus, in which there is a fall in progesterone levels following the high values apparent in the preceding phase (Morissette and Di Paolo, 1993). Our previous data showing that administration of progesterone to male rats for 2 days potentiates the effect of ethanol on cortical dopaminergic neurons (Dazzi et al, 2002a) are in agreement with this hypothesis. Such treatment with progesterone increases expression of the $\delta$ subunit of the $\mathrm{GABA}_{\mathrm{A}}$ receptor and its association with the $\alpha 4$ subunit (Shen et al, 2005), thus possibly increasing the ability of ethanol to increase GABAmediated currents at lower doses.

In conclusion, our data suggest the existence of a modulatory effect of both ovarian steroids on the activity of mesocortical dopaminergic neurons in female rats. Estrogen and progesterone thus appear to have a synergistic effect on ethanol-stimulated dopamine output in the prefrontal cortex during the estrous cycle. Estrogen likely has a stimulatory effect on the activity of this neuronal system, playing a permissive role in the effect of ethanol. Progesterone, through its metabolite $3 \alpha, 5 \alpha$-THPROG, may be necessary to modulate the subunit composition of $\mathrm{GABA}_{\mathrm{A}}$ receptors. Although it is not possible to assign specific roles to estrogen and progesterone in the regulation 
of mesocortical dopaminergic activity, the observation that dopaminergic neurons are sensitive to a synergistic action of circulating steroid levels provides a clue to understanding how fluctuations in ovarian hormone production may amplify or ameliorate the symptomatology of psychiatric disorders characterized by altered mood and emotional states as well as the estrous cycle- and gender-related differences in drug sensitivity.

\section{ACKNOWLEDGEMENTS}

This work was supported by National institute on Alcohol Abuse and Alcoholism Grant U01AA13641, by the Sardinian Health Ministry (no 363, 12.04.05, c. 12076/00), as well as by GIO.I.A. Foundation (Pisa, Italy).

\section{REFERENCES}

Allen D (1996). Are alcoholic women more likely to drink premenstrually? Alcohol Alcohol 31: 145-147.

Bazzett TJ, Becker JB (1994). Sex differences in the rapid and acute effects of estrogen on striatal D2 dopamine receptor binding. Brain Res 637: 163-172.

Becker JB (1990). Direct effect of $\beta$-estradiol on striatum: sex differences in dopamine release. Synapse 5: 157-164.

Becker JB (1999). Gender differences in dopaminergic function in striatum and nucleus accumbens. Pharmacol Biochem Behav 64: 803-812.

Becker JB, Cha J (1989). Estrous cycle-dependent variations in amphetamine-induced behaviors and striatal dopamine release assessed with microdialysis. Behav Brain Res 35: 117-125.

Beyer C (1999). Estrogen and the developing mammalian brain. Anat Embryol 199: 379-390.

Biggio G, Dazzi L, Biggio F, Mancuso L, Talani G, Busonero F et al (2003). Molecular mechanisms of tolerance to and withdrawal of $\mathrm{GABA}_{\mathrm{A}}$ receptor modulators. Eur Neuropsychopharmacol 13: 411-423.

Borghese CM, Storustovu S, Ebert B, Herd MB, Belelli D, Lambert JJ et al (2005). The delta subunit of gamma-aminobutyric acid type A receptors does not confer sensitivity to low concentrations of ethanol. J Pharmacol Exp Ther 316: 1360-1368.

Bowen CA, Purdy RH, Grant KA (1999). An investigation of endogenous neuroactive steroid-induced modulation of ethanol's discriminative stimulus effects. Behav Pharmacol 10: 297-311.

Brodie MS, Appel SB (1998). The effects of ethanol on dopaminergic neurons of the ventral tegmental area studied with intracellular recording in brain slices. Alcohol Clin Exp Res 22: 236-244.

Cagetti E, Liang J, Spigelman I, Olsen RW (2003). Withdrawal from chronic intermittent ethanol treatment changes subunit composition, reduces synaptic function, and decreases behavioral responses to positive allosteric modulators of $\mathrm{GABA}_{\mathrm{A}}$ receptors. Mol Pharmacol 63: 53-64.

Canonaco M, O'Connor LH, Pfaff DW, McEwen BS (1989). GABA A receptor level changes in female hamster forebrain following in vivo estrogen progesterone and benzodiazepine treatment: a quantitative autoradiography analysis. Exp Brain Res 75: 644-652.

Carroll ME, Lynch WJ, Roth ME, Morgan AD, Cosgrove KP (2004). Sex and estrogen influence drug abuse. Trends Pharmacol Sci 25: 273-279.

Childress AR, Mozley PD, McElgin W, Fitzgerald J, Reivich M, O'Brien CP (1999). Limbic activation during cue-induced cocaine craving. Am J Psychiatry 156: 11-18.

Chuong CJ, Burgos DM (1995). Medical history in women with premenstrual syndrome. J Psychosom Obstetr Gynecol 16: 21-27.
Corrêa CL, Oga S (2004). Effects of the menstrual cycle of white women on ethanol toxicokinetics. J Stud Alcohol 65: 227-231.

Dazzi L, Serra M, Seu E, Cherchi G, Pisu MG, Purdy RH et al (2002a). Progesterone enhances ethanol-induced modulation of mesocortical dopamine neurons: antagonism by finasteride. J Neurochem 83: 1103-1109.

Dazzi L, Serra M, Vacca G, Ladu S, Latrofa A, Trapani G et al (2002b). Depletion of cortical allopregnanolone potentiates stress-induced increase in cortical dopamine output. Brain Res 932: 135-139.

Devaud LL, Purdy RH, Morrow AL (1995). The neurosteroid, $3 \alpha-$ hydroxy- $5 \alpha$-pregnane-20-one, protects against bicuculline-induced seizures during ethanol withdrawal in rats. Alcohol Clin Exp Res 19: 350-355.

Di Paolo T, Dupont A, Daigle M (1982). Effect of chronic estradiol treatment on dopamine concentration in discrete brain nuclei of hypophysectomized female rats. Neurosci Lett 32: 295-300.

Di Paolo T, Falardeau P, Morisette M (1988). Striatal D2 dopamine agonist binding sites fluctuate during the rat estrous cycle. Life Sci 43: 665-672.

Di Paolo T, Levesque D, Daigle M (1986). A physiological dose of progesterone affects rat striatum biogenic amine metabolism. Eur J Pharmacol 125: 11-16.

Di Paolo T, Poyet P, Latrie F (1981). Effect of chronic estradiol and haloperidol treatment on striatal dopamine receptors. Eur $J$ Pharmacol 73: 105-106.

Di Paolo T, Rouillard C, Bedard P (1985). 17 $\beta$-Estradiol at a physiological dose acutely increases dopamine turnover in rat brain. Eur J Pharmacol 117: 197-203.

Dluzen DE (2005). Unconventional effects of estrogen uncovered. Trends Pharmacol Sci 26: 485-487.

Engel SR, Grant KA (2001). Neurosteroids and behaviour. In: Biggio G, Purdy RH (eds). Neurosteroids and Brain Function International Review of Neurobiology, vol 46. Academic Press: New York. pp 321-342.

Febo M, Gonzalez-Rodriguez LA, Capò-Ramos DE, GonzalesSegarra NY, Segarra AC (2003). Estrogen-dependent alterations in D2/D3-induced $G$ protein activation in cocaine-sensitized female rats. J Neurochem 86: 405-412.

Finn DA, Ford MF, Wiren KM, Roselli CE, Crabbe JC (2004). The role of pregnane neurosteroids in ethanol withdrawal: behavioral genetic approaches. Pharmacol Ther 101: 91-112.

Follesa P, Biggio F, Caria S, Gorini G, Biggio G (2004). Modulation of $\mathrm{GABA}_{\mathrm{A}}$ receptor gene expression by allopregnanolone and ethanol. Eur J Pharmacol 500: 413-425.

Follesa P, Mancuso L, Biggio F, Mostallino MC, Manca A, Mascia MP et al (2003). Gamma-hydroxybutyric acid and diazepam antagonize a rapid increase in $\mathrm{GABA}_{\mathrm{A}}$ receptor $\alpha_{4}$ subunit mRNA abundance induced by ethanol withdrawal in cerebellar granule cells. Mol Pharmacol 63: 896-907.

Follesa P, Porcu P, Sogliano C, Cinus M, Biggio F, Mancuso L et al (2002). Changes in $\mathrm{GABA}_{\mathrm{A}}$ receptor $\gamma 2$ subunit gene expression induced by long-term administration of oral contraceptives in rats. Neuropharmacology 42: 325-336.

Follesa P, Serra M, Cagetti E, Pisu MG, Porta S, Floris S et al (2000). Allopregnanolone synthesis in cerebellar granule cells: roles in regulation of $\mathrm{GABA}_{\mathrm{A}}$ receptor expression and function during progesterone treatment and withdrawal. Mol Pharmacol 57: $1262-1270$.

Frye CA, Duncan JE (1996). Estradiol benzoate potentiates neuroactive steroids' effects on pain sensitivity. Pharmacol Biochem Behav 53: 27-32.

Frye CA, Rhodes ME (2005). Estrogen-priming can enhance progesterone's anti-seizure effects in part by increasing hippocampal levels of allopregnanolone. Pharmacol Biochem Behav 81: 907-916.

Garcia-Segura LM, Azcoitia I, DonCarlos LL (2001). Neuroprotection by estradiol. Prog Neurobiol 63: 29-60. 
Goldman-Rakic PS (1987). Circuitry of the primate prefrontal cortex and the regulation of behavior by representational memory. In: Plum F (ed). Handbook of Physiology: The Nervous System Higher Functions of the Brain. American Physiological Society: Bethesda, MD. pp 373-417.

Grace AA (2000). The tonic/phasic model of dopamine system regulation and its implications for understanding alcohol and psychostimulant craving. Addiction 95(Suppl 2): 119-128.

Griffiths JL, Lovick TA (2005). GABAergic neurons in the periaqueductal grey matter express $\alpha 4, \beta 1$ and $\delta \mathrm{GABA}_{\mathrm{A}}$ receptor subunits: plasticity of expression during the estrous cycle. Neuroscience 136: 457-466.

Gulinello M, Smith SS (2003). Anxiogenic effects of neurosteroid exposure: sex differences and altered $\mathrm{GABA}_{\mathrm{A}}$ receptor pharmacology in adult rats. J Pharmacol Exp Ther 305: 541-548.

Hruska RE (1986). Elevation of striatal dopamine receptors by estrogen: dose and time studies. J Neurochem 47: 1908-1915.

Hruska RE, Silbergeld EK (1980). Increased dopamine receptor sensitivity after estrogen treatment using the rat rotation model. Science 208: 1466-1468.

Jablonka-Shariff A, Ravi S, Beltsos AN, Murphy LL, Olson LM (1999). Abnormal estrous cyclicity after disruption of endothelial and inducible nitric oxide synthase in mice. Biol Reprod 61: 171-177.

Jentsch JD, Redmond Jr DE, Elsworth JD, Taylor JR, Youngren KD, Roth RH (1997). Enduring cognitive deficits and cortical dopamine dysfunction in monkeys after long-term administration of phencyclidine. Science 277: 953-955.

Koob GF, Roberts AJ, Schulteis G, Parsons LH, Heyser CJ, Hyytia P et al (1998). Neurocircuitry targets in ethanol reward and dependence. Alcohol Clin Exp Res 22: 3-9.

Landgren S, Selstam G (1995). Interaction between $17 \beta$-oestradiol and $3 \alpha$-hydorxy-5 $\alpha$-pregnane-20-one in the control of neuronal excitability in slices from the CA1 hippocampus in vitro of guinea-pigs and rats. Acta Physiol Scand 154: 165-176.

Leranth C, Roth RH, Elsworth JD, Naftolin F, Horvath TL, Redmond Jr DE (2000). Estrogen is essential for maintaining nigrostriatal dopamine neurons in primates: implications for Parkinson's disease and memory. J Neurosci 20: 8604-8609.

Lovick TA, Griffiths JL, Dunn SM, Martin IL (2005). Changes in $\mathrm{GABA}_{\mathrm{A}}$ receptor subunit expression in the midbrain during the oestrous cycle in Wistar rats. Neuroscience 131: 397-405.

Lynch WJ, Roth ME, Carroll ME (2002). Biological basis of sex differences in drug abuse: preclinical and clinica studies. Psychopharmacology 164: 121-137.

Maguire JL, Stell BM, Rafizadeh M, Mody I (2005). Ovarian cycle-linked changes in $\mathrm{GABA}_{\mathrm{A}}$ receptors mediating tonic inhibition alter seizure susceptibility and anxiety. Nat Neurosci 8: 797-804.

Majewska MD (1992). Neurosteroids: endogenous bimodal modulators of the $\mathrm{GABA}_{\mathrm{A}}$ receptor. Mechanism of action and physiological significance. Prog Neurobiol 38: 379-395.

Majewska MD, Harrison NL, Schartz RD, Barker JL, Paul SM (1986). Steroid hormone metabolites are barbiturate-like modulators of the GABA receptor. Science 232: 1004-1007.

McEwen BS, Parsons B (1982). Gonadal steroid action on the brain: neurochemistry and neuropharmacology. Annu Rev Pharmacol Toxicol 22: 555-598.

Mermelstein PG, Becker JB, Surmeier DJ (1996). Estradiol reduces calcium currents in rat neostriatal neurons through a membrane receptor. J Neurosci 16: 598-604.

Morissette M, Di Paolo T (1993). Sex and estrous cycle variations of rat striatal dopamine uptake sites. Neuroendocrinology 58: $16-22$.

Morrow AL, VanDoren MJ, Penland SN, Matthews DB (2001). The role of GABAergic neuroactive steroids in ethanol action, tolerance and dependence. Brain Res Rev 37: 98-109.
Motzo C, Porceddu ML, Maira G, Flore G, Concas A, Dazzi L et al (1996). Inhibition of basal and stress-induced dopamine release in the cerebral cortex and nucleus accumbens of freely moving rats by the neurosteroid allopregnanolone. J Psychopharmacol 10: 266-272.

Naftolin F, Mor G, Horvath TL, Luquin S, Fajer AB, Kohen F et al (1996). Synaptic remodeling in the arcuate nucleus during the estrous cycle is induced by estrogen and precedes the preovulatory gonadotropin surge. Endocrinology 137: 5576-5580.

Paxinos G, Watson C (1982). The Rat Brain in Stereotaxic Coordinates. Academic Press: New York.

Phillips TJ, Shen EH (1996). Neurochemical bases of locomotion and ethanol stimulant effects. Int Rev Neurobiol 39: 243-282.

Pierce RC, Kalivas PW (1997). A circuitry model of the expression of behavioral sensitization to amphetamine-like psychostimulants. Brain Res Rev 25: 192-216.

Robinson DL, Brunner LJ, Gonzales RA (2002). Effect of gender and estrous cycle on the pharmacokinetics of ethanol in the rat brain. Alcohol Clin Exp Res 26: 165-172.

Roth ME, Cosgrove KP, Carroll ME (2004). Sex differences in the vulnerability to drug abuse: a review of preclinical studies. Neurosci Biobehav Rev 28: 533-546.

Samson HH, Hodge CW, Erickson HL, Niehus JS, Gerhardt GA, Kalivas PW et al (1997). The effects of local application of ethanol in the $n$. accumbens on dopamine overflow and clearence. Alcohol 14: 485-492.

Sanna E, Mostallino MC, Busonero F, Talani G, Tranquilli S, Mameli $\mathrm{M}$ et al (2003). Changes in $\mathrm{GABA}_{\mathrm{A}}$ receptor gene expression associated with selective alterations in receptor function and pharmacology after ethanol withdrawal. J Neurosci 23: $11711-11724$.

Sanna E, Talani G, Busonero F, Pisu MG, Purdy RH, Serra M et al (2004). Brain steroidogenesis mediates ethanol modulation of $\mathrm{GABA}_{\mathrm{A}}$ receptor activity in rat hippocampus. J Neurosci 24: 6521-6530.

Savage LM, Candon PM, Hohmann HL (2000). Alcohol-induced brain pathology and behavioral dysfunction: using an animal model to examine sex differences. Alcohol Clin Exp Res 24: 465-475.

Sawada H, Shimohama S (2003). Estrogens and Parkinson disease: novel approach for neuroprotection. Endocrine 21: 77-79.

Scharfman HE, Mercurio TC, Goodman JH, Wilson MA, MacLusky NJ (2003). Hippocampal excitability increases during the estrous cycle in the rat: a potential role for brain-derived neurotrophic factor. J Neurosci 23: 11641-11652.

Shen H, Gong QH, Yuan M, Smith SS (2005). Short-term steroid treatment increases $\delta \mathrm{GABA}_{\mathrm{A}}$ receptor subunit expression in rat CA1 hippocampus: pharmacological and behavioral effects. Neuropharmacology 49: 573-586.

Stein DG (2001). Brain damage, sex hormones and recovery: a new role for progesterone and estrogen? Trends Neurosci 24: 386-391.

Sundstrom-Poromaa I, Smith DH, Gong QH, Sabado TN, Li X, Light $\mathrm{A}$ et al (2002). Hormonally regulated $\alpha 4 \beta 2 \delta \mathrm{GABA}_{\mathrm{A}}$ receptors are a target for alcohol. Nat Neurosci 5: 721-722.

Sutton SK, Davidson RJ (1997). Prefrontal brain asymmetry: a biological substrate of the behavioral approach and inhibition systems. Am Psychol Soc 8: 204-210.

Tanapat P, Hastings NB, Reeves AJ, Gould E (1999). Estrogen stimulates a transient increase in the number of new neurons in the dentate gyrus of the adult female rat. J Neurosci 19: 5792-5801.

Thompson TL, Bridges SR, Weirs WJ (2001). Alteration of dopamine transport in the striatum and nucleus accumbens of ovariectomized and estrogen-primed rats following $\mathrm{N}$-(p-isothiocyanatophenethyl) spiperone (NIPS) treatment. Brain Res Bull 54: 631-638.

Thompson TL, Moss RL (1997). Modulation of mesolimbic dopaminergic activity over the rat estrous cycle. Neurosci Lett 229: $145-148$. 
Tobin MB, Schmidt PJ, Rubinow DR (1994). Reported alcohol use in women with premenstrual syndrome. Am J Psychiatry 151: 1503-1504.

Trapani G, Dazzi L, Pisu MG, Seu E, Biggio G (2002). A rapid method for obtaining finasteride, a $5 \alpha$-reductase inhibitor, from commercial tablets. Brain Res Prot 9: 130-134.

Tzschentke TM (2001). Pharmacology and behavioral pharmacology of the mesocortical dopamine system. Prog Neurobiol 63: 241-320.

VanDoren MJ, Matthews DB, Janis GC, Grobin AC, Devaud LL, Morrow AL (2000). Neuroactive steroid $3 \alpha$-hydroxy- $5 \alpha$-pregnan20-one modulates electrophysiological and behavioral actions of ethanol. J Neurosci 20: 1982-1989.

Wafford KA, Thompson SA, Thomas D, Sikela J, Wilcox AS, Whiting PJ (1996). Functional characterization of human $\gamma$ aminobutyric $\operatorname{acid}_{\mathrm{A}}$ receptors containing the $\alpha 4$ subunit. Mol Pharmacol 50: 670-678.

Wallner M, Hanchar HJ, Olsen RW (2004). Ethanol enhances $\alpha 4 \beta 3 \delta$ and $\alpha 6 \beta 3 \delta \gamma$-aminobutyric acid type $\mathrm{A}$ receptors at low concentrations known to affect humans. Proc Natl Acad Sci USA 100: $15218-15223$.

Wihlback AC, Nyberg S, Backstrom T, Bixo M, Sundstrom-Poromaa I (2005). Estradiol and the addition of progesterone increase the sensitivity to a neurosteroid in postmenopausal women. Psychoneuroendocrinology 30: 38-50.

Wolf ME (1998). The role of excitatory amino acids in behavioral sensitization to psychomotor stimulants. Prog Neurobiol 54: 679-720.

Xiao L, Becker JB (1994). Quantitative microdialysis determination of extracellular striatal dopamine concentration in male and female rats: effects of estrous cycle and gonadectomy. Neurosci Lett 180: 155-158.

Zhou W, Cunningham KA, Thomas ML (2002). Estrogen regulation of gene expression in the brain: a possible mechanism altering the response to psychostimulants in female rats. $\mathrm{Mol}$ Brain Res 100: 75-83. 